\title{
情報機器の進化に貢献する素材 “シクロオレフィンポリマー”
}

\author{
宮澤 慎介* \\ "Cyclo Olefin Polymer" the Material Which Contributes to the Progress in Information Devices
}

Shinsuke MIYAZAWA*

*日本ゼオン株式会社総合開発センター高機能樹脂研究所製品開発チーム（† 210-9507 神奈川県川崎市川崎区夜光 1-2-1）

* Product Development Team, Specialty Plastics Lab., R\&D Center, ZEON CORPORATION (1-2-1 Yako, Kawasaki-ku, Kawasaki-shi, Kanagawa 210-9507)

\section{1. はじめに}

シクロオレフィンポリマー（以下 COP と略す）は, シク ロオレフィン類をモノマーとして合成される脂環構造を有 するポリマー (Fig. 1) である。COP は, 炭化水素系の非極 性ポリマーであり, その優れた光学特性から主に光学レン ズや液晶部材向けに市場展開されている ${ }^{1) \sim 4) 。 ~}$

一方, 非極性な COP は誘電特性にも優れていることが知 られており, 電子回路用基板としての用途展開が期待され ていた。しかし, それ単体での使用においては導体との密 着性に劣る欠点があり, 電子回路基板としての実用化が困 難であった。

その課題を克服する方法として, 紫外線(UV)によりCOP 層表面を改質し, めっきした導体（ここでは銅）との密着 性を向上させる技術が報告されている ${ }^{5)}$ 。そこでわれわれ は, 基板として COP を溶融押出にて成形した COP フィル ムを用い, その表面を UV 処理にて改質後, 銅めっき処理 を行うことにより, 銅めっきCOP フィルム（銅張積層 COP フィルム）を作成した。本稿では, その電気特性, および 信頼性の検証結果について説明する。

さらに, 高周波部品向けに, 射出成形が可能な材料とし て開発したCOP「ZEONEX ${ }^{\circledR}$ RS420」の特性および, 最近 のトピックスとして, 現在開発中の耐熱性 COP についても 述べる。

\section{2. 銅めっきCOP フィルムの特性検証}

\subsection{COP フィルムの誘電特性}

COP フィルムとして, 溶融押出成形にてフィルム化した Zeonor Film $^{\circledR}$ (ZF-16, 膜厚 $0.1 \mathrm{~mm}$, 日本ゼオン社製）を用 いた。そのマイクロ波領域での比誘電率, 誘電正接測定 は, 円筒空洞共振器 (サムテック製) を用いた。また, ミ リ波領域での測定は，遮断円筒導波管（サムテック製）を 用いて行った 6)。測定結果を Fig. 2 に示す。Fig. 2 には, 比 較として $1 \mathrm{GHz}$ でのポリエチレンテレフタレート (PET) フィルム, ポリテトラフルオロエチレン (PTFE) フィルムの

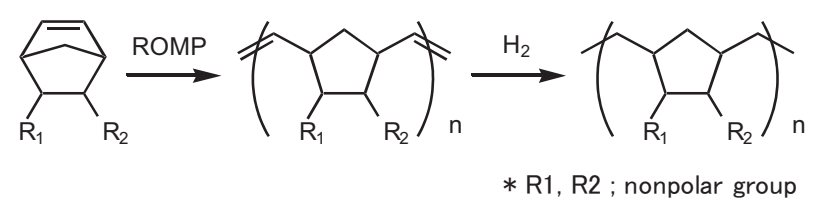

Fig. 1 Synthesis of Cyclo Olefin Polymer

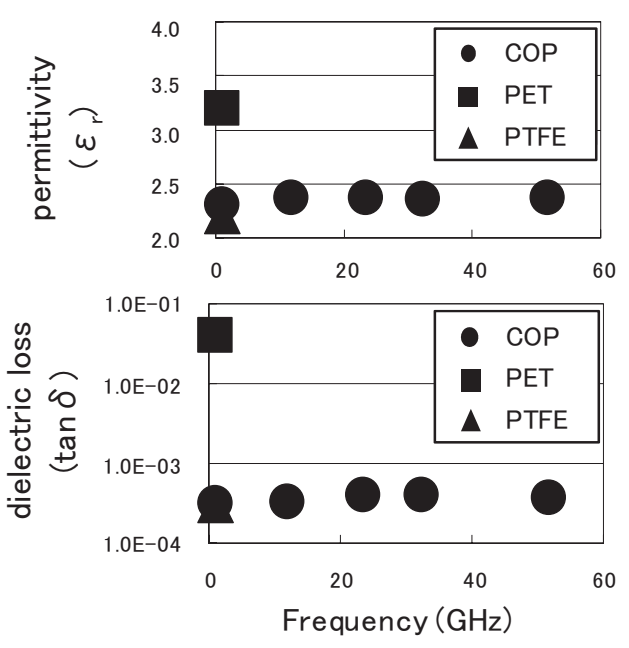

Fig. 2 Dielectric properties of a COP film in high frequency region

データも示す。Fig. 2 より, COP フィルムは, ミリ波領域 において比誘電率・誘電正接がほとんど変化せず, PTFE フィルム同等の誘電特性をもつことがわかる。

\section{$2.2 \mathrm{COP}$ フィルムと銅めっき層との密着性検証}

COP フィルムとして, 前述の Zeonor Film ${ }^{\circledR}$ （ZF-16，膜 厚 $0.1 \mathrm{~mm}$ ）を使用し，UV 処理による表面改質ののちに銅 めっき処理を行った。その作成フローを Fig. 3 に示す。表 面改質処理は, 低圧水銀ランプを備えた UV 照射装置（江 東電気製）を用いて，大気中にてサンプルを 5 分間照射し て行った。その後, 触媒処理, 無電解めっき, 電気めっき プロセスを行うことにより，銅めっき COP フィルムを得 た。

形成した銅めっき層とCOP フィルムの密着性は, $1.2 \mathrm{kN} / \mathrm{m}$ 


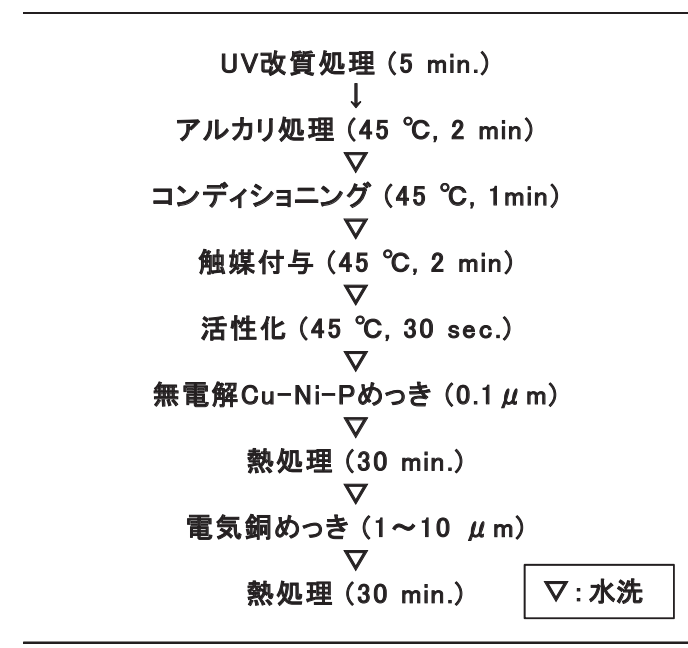

Fig. 3 A procedure of copper plating process

であった。UVで処理しない COP フィルム上へ銅めっき層 を形成した場合は，めっき層が容易にはがれることから， COP フィルム表面を UV 処理にて改質することで, 導体と の良好な密着性を付与することができることがわかる。

2.3 銅めっき層と COP フィルムの界面観察による高周 波特性の検証

銅めっきCOP フィルムの界面観察（TEM-EDX による断 面観察）を行った。Fig. 4 にその TEM-EDX による元素分 析結果を示す。Fig. 4 より, 銅めつき層と COP フィルムの 間にそれぞれが混ざり合った層 (浸透層) が存在し, その 厚みは $0.1 \mu \mathrm{m}$ 以下であることがわかる。すなわち, UV 処 理により樹脂表面に数十ナノメートルオーダーの微細な凹 凸が形成され，そのアンカー効果により COP フィルムと銅 めっきとの間に優れた密着性が発現していると考えられ る。また，基板表面の平滑性は，高周波伝送特性に対する 影響が大きい。表面が平滑なほど伝送特性に優れるため, $\mathrm{UV}$ 処理銅めっき COP フィルムを用いた回路基板は，通常 の回路基板と比べ高周波伝送特性に優れることが示唆され る。

\section{4 界面比導電率測定による高周波特性の検証}

界面比導電率 $\left(\sigma_{r b}\right)$ とは, 導体層と誘電体層の界面付近の 導体の万国標準軟銅 $\left(\sigma_{0}=58 \times 10^{6} \mathrm{~S} / \mathrm{m}\right)$ に対する比導電率 (\%)である。導電率は, 抵抗 (損失) の逆数の定数倍であ るため, 導電率が大きいほど損失が小さく伝送特性に優れ ることを意味する。界面導電率は, MIC 形誘電体共振器法 (サムテック製) により測定した ${ }^{6}$ 。

銅めっき COP フィルムの $\sigma_{r b}$ を Fig. 5 に示す。Fig. 5 に は，比較として PTFE 銅張板の $\sigma_{r b}$ も示す。Fig. 5 より，測 定周波数 $5 \mathrm{GHz}, 10 \mathrm{GHz}$ において PTFE 銅張板の $\sigma_{r b}$ は 50 $\%$ 程度であるのに対し, 銅めっき COP フィルムの $\sigma_{r b}$ は 90 $\%$ 以上であった。この結果は，Fig. 2 より材料自身の誘電 正接はほぼ変わらないことから, 銅めっき COP フィルムに おける導体層と誘電体層界面の平滑性に起因すると考えら

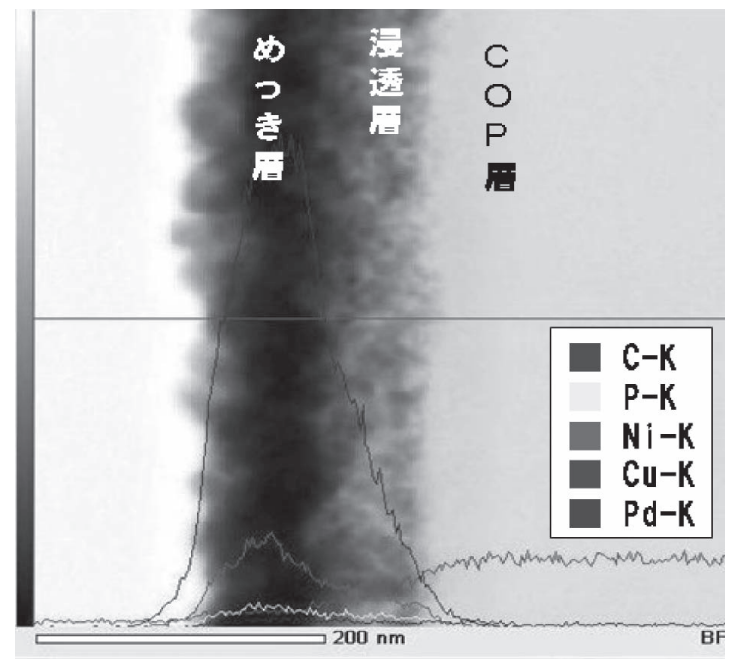

Fig. 4 TEM-EDX analysis for a copper plated COP Film (a closs section around the interface area)

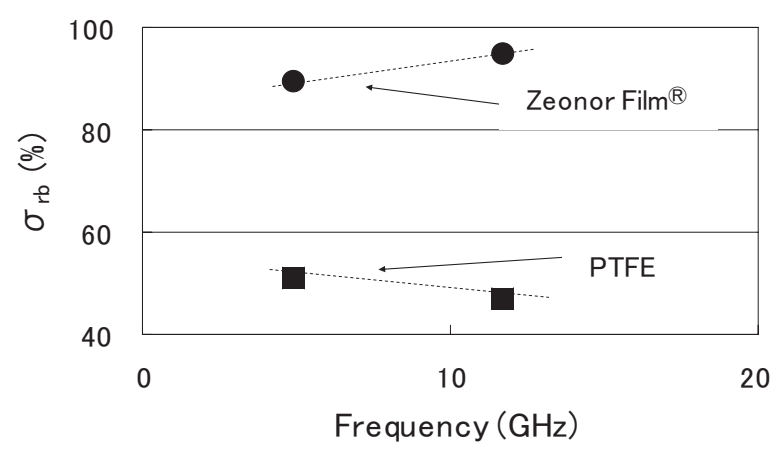

Fig. 5 Relative near boundary layer conductivity of a copper plated COP film

れる。先の TEM-EDXによる結果とも一致し, 銅めっき COP フィルムが高周波伝送特性に優れる可能性があること を示唆する結果である。

\section{5 銅めっき COP フィルムにより作成した回路基板の 信頼性評価}

銅めっき COP フィルムの信頼性評価を行った。

(1)耐熱耐湿試験：通常のフォトリソ／エッチング加工に より, $\mathrm{L} / \mathrm{S}=50 / 50 \mu \mathrm{m}$ くし型対向電極回路基板を作成 し， $85^{\circ} \mathrm{C} ， 85 \% \mathrm{Rh}, 1,000$ 時間による銅マイグレーショ ンの確認を行った。その結果，マイグレーションによ る対向電極間の導通は観測されなかった。

(2)冷熱サイクル衝撃試験：0.15 mm $\phi$ のビアを形成し, 銅 めっき COP フィルムの表裏両面にビア間に交互に配線 を形成し，デイジーチェーンを作成したテストパター ン回路基板を用いて, $-40^{\circ} \mathrm{C} \sim 85^{\circ} \mathrm{C}, 1,000$ サイクルに よる断線の確認を行った。その結果，断線による導通 不良は観測されなかった。 


\section{3. 高周波部品向け射出成形用 COP の特性}

\section{1 高周波部品向け射出成形用 COP の特長}

高周波用部品向け材料として代表的なものに, PTFEな どのフッ素系ポリマーがある。これらは, 融点が非常に高 いために熱可塑性樹脂の一般的な加工法である射出成形が 適用できず，加工自由度が低いことが課題となっている。

そこで, 高周波部品向け射出成形用 COP として開発した $Z_{\text {ZEONEX }}^{\circledR}$ RS420 は, 溶融成形が可能で加工自由度が高い ことが特徴である。また, COP の特長である低誘電率, 低 誘電正接, 低吸水を保ちつつ, 高周波用部品向け材料とし て実用可能なめっき密着力が得られるように配合設計され た材料である。
また非晶性樹脂のため, 誘電率の異方性がないことも大 きな特長となっている ${ }^{7)}$ 。

Table 1 に,「ZEONEX ${ }^{\circledR}$ RS420」の一般特性を示す。

\section{2 電気特性}

Fig. 6 に各種プラスチックの電気特性を示す。LCR メー ターを用い $1 \mathrm{MHz}$ での誘電正接と誘電率を求めた（ASTMD150 に準拠)。高周波部品向け射出成形用 COP は PTFE に 近い低誘電正接と低誘電率を示すことがわかる。

さらにトリプレート線路共振器法によって 1 25 GHz 高 周波領域での誘電正接を測定した。その結果を Fig. 7 に示 す。Fig. 7 には比較として, PTF およびスチレン系ポリマー の值も示す。高周波部品向け射出成形用 COP は, 高周波領 域でも低誘電正接性を示し，周波数依存性も PTFE 並みと

Table 1. General properties of ZEONEX ${ }^{\circledR}$ RS420

\begin{tabular}{l|c|c|c|c}
\hline \multicolumn{1}{c|}{ Properties } & Unit & Test Method & Condition & ZEONEX $^{\circledR}$ RS420 $^{-}$ \\
\hline Density & $\mathrm{g} / \mathrm{cm}^{3}$ & ASTMD792 & - & 1.01 \\
\hline Water Absorption & $\%$ & ASTM D570 & - & $<0.01$ \\
\hline Light Transmittance & $\%$ & ASTM D1003 & 3 mm Thickness & Opaque White \\
\hline Glass Transition Temperature & ${ }^{\circ} \mathrm{C}$ & DSC & - & 136 \\
\hline Heat Distortion Temperature & ${ }^{\circ} \mathrm{C}$ & ISO75 & 1.80 Mpa Nonannealing & 110 \\
\hline Linear Expansion Coefficient & $\mathrm{cm} / \mathrm{cm}^{\circ} \mathrm{C}$ & ASTM D696 & - & $7 \times 10^{-5}$ \\
\hline Melt FlowIndex & $\mathrm{g} / 10 \mathrm{~min}$ & JIS K6719 & $280^{\circ} \mathrm{C} 21.18 \mathrm{~N}$ & 7 \\
\hline Flexural Modulus & $\mathrm{MPa}$ & ISO178 & - & 1,600 \\
\hline Flexural Strength & $\mathrm{MPa}$ & ISO178 & - & 64 \\
\hline Tensile Modulus & $\mathrm{MPa}$ & ISO527 & - & 1,700 \\
\hline Tensile Strength & $\mathrm{MPa}$ & ISO527 & - & 45 \\
\hline Tensile Elongation & $\%$ & ISO527 & - & 135 \\
\hline Izod Impact & $\mathrm{J} / \mathrm{m}$ & ASTM D256 & $3.2 \mathrm{~mm} \mathrm{Unnotched}$ & 510 \\
\hline Pencil Hardness & - & JIS K5401 & - & B \\
\hline Volume Resistivity & $\Omega \mathrm{cm}$ & ASTM D257 & - & $410^{16}$ \\
\hline Dielectric Strength & $\mathrm{kV} / \mathrm{mm}$ & ASTM D149 & $1 \mathrm{~mm}$ & 2.3 \\
\hline Dielectric Constant & - & ASTM D150 & $1 \mathrm{MHz}$ & 0.0002 \\
\hline Dissipation Factor & - & ASTM D150 & $1 \mathrm{MHz}$ & $94 \mathrm{HB}$ \\
\hline Flame Rating & - & UL94 & - & Connector Antenna \\
\hline Main Application & - & - & - &
\end{tabular}

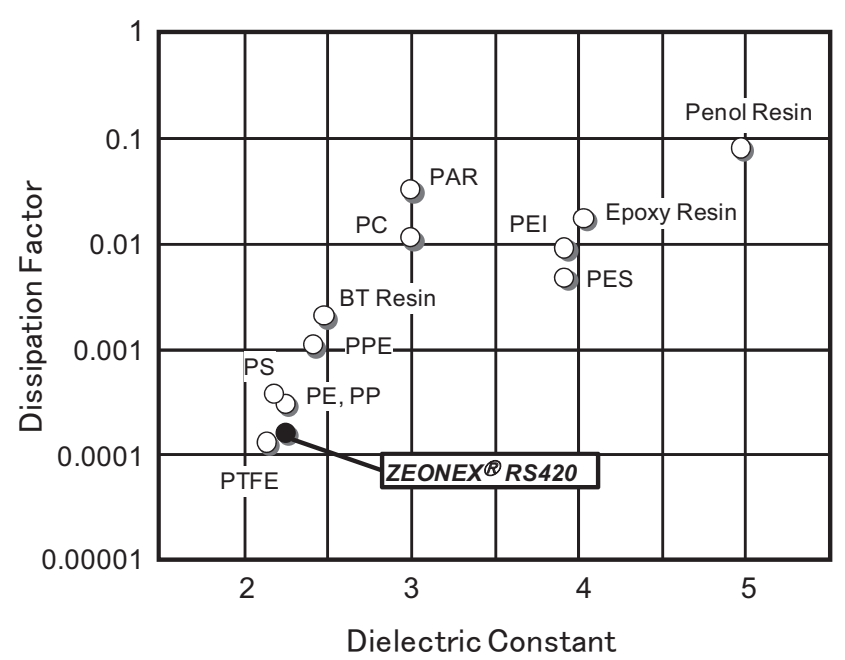

Fig. 6 Electric properties of plastics

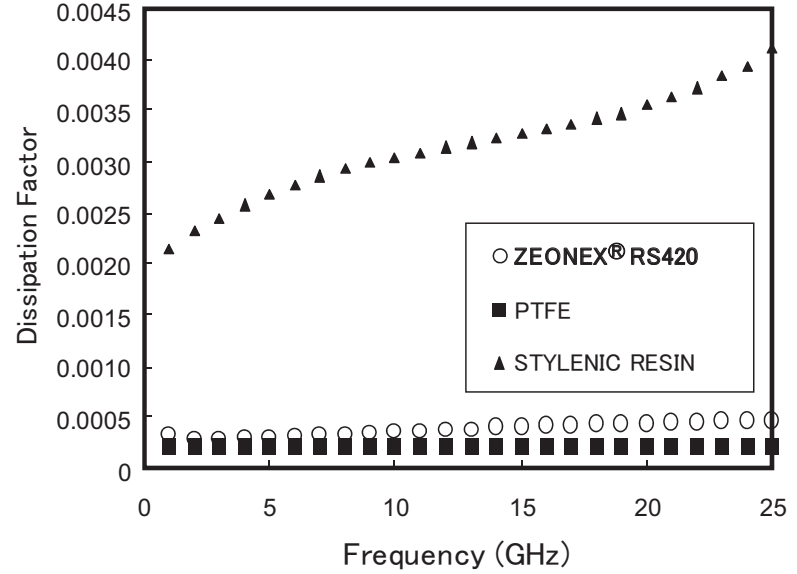

Fig. 7 Dissipation factors of plastics in high frequency region 


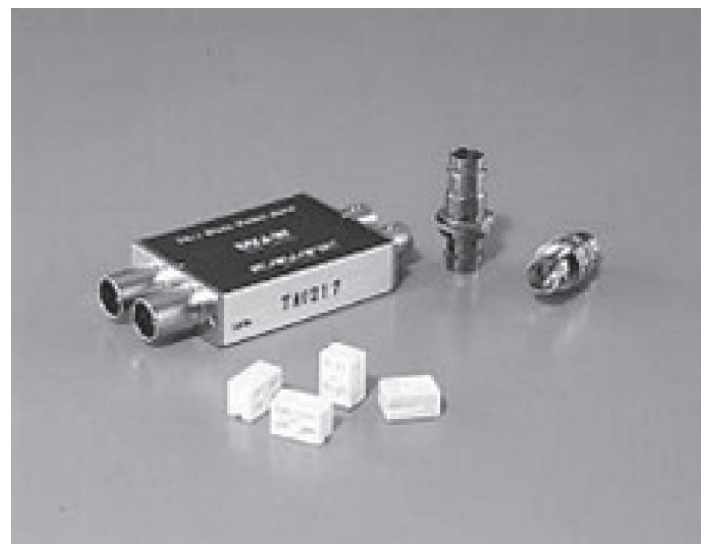

Fig. 8 Application example of ZEONEX ${ }^{\circledR}$ RS420 (connector)

非常に小さいことがわかる。

また，電気特性の温度依存性や耐湿試験前後での変化も 少ないことが確認できている。上記を含めて，高周波部品 向け射出成形用 COP が電気特性に優れるのは, 極性置換基 を持たず分子内の電荷の偏りが小さいことや, 吸水による 水分の影響を受けないことが起因していると考えられる。

\section{3 用途展開}

高周波部品向け射出成形用 COP は, 携帯電話などのモバ イル通信端末のアンテナ基板やコネクタ部品などに実用化 されており, 今後はミリ波デバイスなどへの展開が期待さ れている。

\section{4. 最近のトピックス}

\section{1 耐熱性 COP の開発}

従来, 電子回路などの基板に電子部品を接合するため に，鉛と錫の合金であるはんだが使用されていた。しか し，鉛は人体に有害であり，また廃裹物としての自然環境 に対する悪影響も懸念されたため, 自動車分野や電子・電 気分野を中心に鉛を含まない鉛フリーはんだの普及が進め られている。鉛フリーはんだは，一般的な鉛はんだと比べ て融点が $20 \sim 30^{\circ} \mathrm{C}$ 高く, $260^{\circ} \mathrm{C}$ 前後でのリフローはんだ付 け工程が必要となる。そのため, 樹脂を含む周辺部材にも 高い耐熱性が求められる。このような環境下に耐えられる 熱可塑性樹脂としては, 液晶ポリマー (LCP), ポリフタル アミド (PPA), ポリフェニレンサルファイド (PPS) などと いった耐熱性に優れたスーパーエンジニアリングプラス チックに限られている。しかし，これら耐熱性に優れる材 料は, 加工性が悪い, リフローはんだ付け工程中に色調が 低下する，といった課題を抱えている ${ }^{8)}$ 。

当社では，独自の分子設計を行うことにより，COP が本 来有する低吸水性, 低誘電正接の電気特性などを保持し, 耐熱性を付与した新しい材料の開発にも取組んでいる。重 合における規則性の制御を行うことで, $260^{\circ} \mathrm{C}$ 以上の融点 をもち, 耐リフロー性を有する耐熱性 COP の設計に成功し た。本耐熱性 COP は，実装でリフロー工程を有する，LED

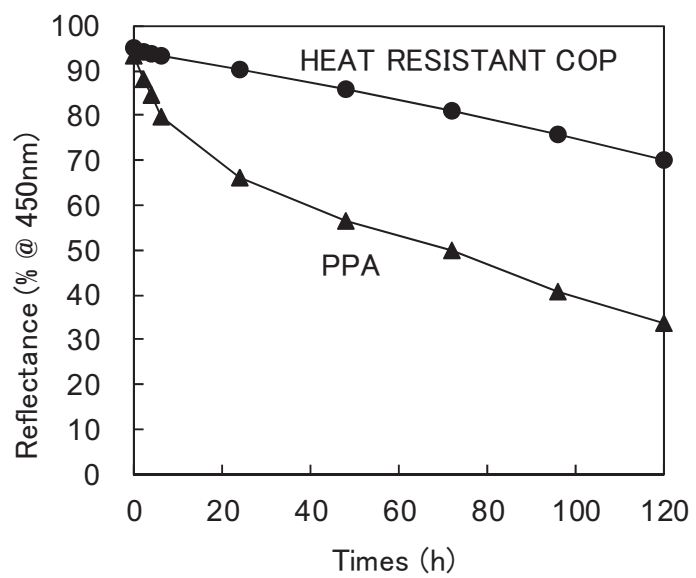

Fig. 9 Light Reflectance of Heat Resistant COP (under development)

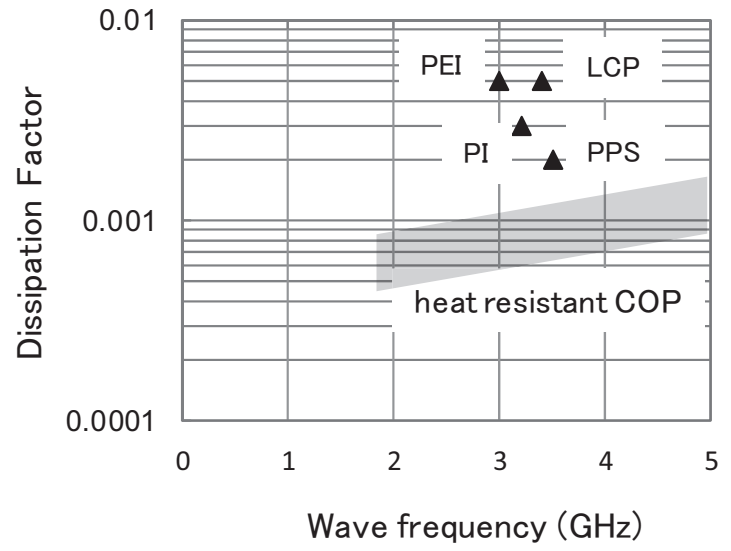

Fig. 10 Dissipation factor of Heat Resistant COP (under development)

リフレクタ用材料や高周波アンテナ基板用材料などへの用 途展開を検討している。耐熱性 COP は，高温環境下におい ても変色せず高い反射率を維持することを特長としており (Fig. 9), また，他のスーパーエンジニアリングプラスチッ クに比べて，低い誘電正接を有している (Fig. 10)。

\section{5. おわりに}

以上, $\operatorname{COP}$ の電気・電子分野への適用を中心に, その新 たな展開について説明した。

COP フィルムの表面をUV 処理することで, 非極性な COP と銅めっき層との密着性を十分に改善した。この技術 により，COPをフレキシブルプリント配線板に適用するこ とが可能となった。

また, 高周波部品向け射出成形用 COP は, 低誘電特性, 低吸水性といった COP の特長を維持したままめっき密着力 を向上させた材料である。フッ素樹脂同などの電気特性を 有する加工特性の優れた材料であり，これまでにない新た な電子部品設計や省エネルギ機器の設計に貢献できると考 える。 
COP は，その優れた特長を活かして，従来の光学分野だ けでなく電気・電子分野などさまざまな用途に展開されて いる。しかし，いずれの分野においても技術の進化は目ま ぐるしく, 材料に求められる要求ハードルも日々高まって おり，市場ニーズを的確に捉えた材料開発が益々必要に なってくる。今回紹介したように, COP は, それら市場 ニーズに応え得る潜在能力を十分に秘めた材料である。今 後も研究開発を進めることで, COP の新たな特長が引き出 され，市場ニーズに応え続ける材料となることを期待する。

(2013.6.7- 受理)

\section{文献}

1) 小原禎二：“工業材料としてのポリマー,”高分子, Vol. 57, No. 8, pp. 613-616, 2008

2) 勝亦 徹: “2009 年日本プラスチック産業の展望,” プラス チックス, Vol. 60, No. 1, pp. 73-76, 2009

3) 熊沢英明 : “拡大する光学部品の市場と技術動向, ” プラス チックエージ，Vol. 53, No. 5, pp. 87-90, 2007

4) 本間精一: “新・社会人のための「高機能」プラスチック材 料入門,” プラスチックエージ, Vol. 55, No. 5, pp. 104-109, 2009
5) 西村宜幸, 新城沙耶加, 馬場邦人, 渡辺充広, 本間英夫 : “UV 改質処理を用いたシクロオレフィンポリマーフィルム 上へのメタライジング, ” 2010 年エレクトロニクス実装学 会講演大会 $11 \mathrm{~A}-18$

6) 和田山修平, 小林禧夫, 馬 哲旺：“シクロオレフィンポリ マー基板のマイクロ波・ミリ波特性測定,”2010 年エレク トロニクス実装学会講演大会 11B-16

7) 蓮池健一, 川端広一, 加藤正之, 小林禧夫 : “コンポジット 共振器を用いたデュアルバンド帯域通過フィルターその 2 , 電子情報通信学会総合大会講演論文集, CS-3-2, 2006

8) 仲田一尋 : “2012 年プラスチック産業の展望,”プラスチッ クス, Vol. 63, No. 1, pp. 73-78, 2012

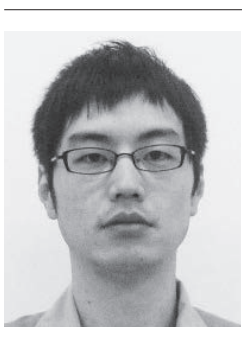

宮澤慎介（みやざわ しんすけ）

著者紹介 2007 年 4 月 日本ゼオン（株）入社 現在高機能樹脂研究所 研究員 